\title{
STATIS-CoA: A methodological solution to assess the spatio-temporal organization of species assemblages. Application to the demersal assemblages of the French Mediterranean Sea*
}

\author{
JEAN CLAUDE GAERTNER ${ }^{1}$, JACQUES A. BERTRAND ${ }^{2}$ and ARNAULD SOUPLET ${ }^{3}$ \\ ${ }^{1}$ Centre d'Océanologie de Marseille, Rue de la Batterie des Lions, 13008 Marseille Cedex, France. \\ E-mail: gaertner@com.univ-mrs.fr \\ 2 IFREMER, Laboratoire Ecologie Halieutique, Rue de l'Ile d'Yeu, BP 21105, 44311 Nantes cedex 03, France. \\ 3 IFREMER, Laboratoire Ressources Halieutiques, Boulevard Jean Monnet, BP 171, 34203 Sète Cedex, France.
}

\begin{abstract}
SUMMARY: The organizational patterns of demersal assemblages (fish, crustaceans and cephalopods) in the Gulf of Lions were investigated on the basis of a set of six bottom trawl surveys performed between 1994 and 1999 (MEDITS programme). The use of a recent multitable method (STATIS-CoA) provided a detailed representation of the stable and variable parts of the spatial organization of demersal assemblages during the studied period. We showed that demersal assemblages of the Gulf of Lions were organized along a coast-open sea gradient. At the scale of the Gulf, we showed that this gradient can be split into three areas: 1) the coastal region and the continental shelf (10 to $200 \mathrm{~m}$ depth), 2) the upper slope (200 to $500 \mathrm{~m}$ ) and 3) the deeper slope $(500$ to $800 \mathrm{~m}$ ). Associated to this bathymetric structuring we found a species-richness gradient which decreases from the coast to the upper slope. Our analysis showed that this spatial organization pattern was highly persistent during the course of the study. However, some species caught in the slope area exhibited a strong variability of their spatial distribution mainly during the 1999 survey. From a methodological point of view, STATIS-CoA offers a rigorous theoretical framework for the simultaneous analysis of a three-dimensional set of data. Applied in the field of fisheries ecology, this method (1) constitutes a relevant way to analyse the spatial organization of species assemblages and its pattern of changes, and (2) could be of particular interest to treat the MEDITS data both at a local and at the North Mediterranean Sea scales.
\end{abstract}

Key words: demersal assemblages, trawl surveys, MEDITS, STATIS-CoA, multitable analyses, Mediterranean Sea.

\section{INTRODUCTION}

Numerous experimental trawl survey programmes have been conducted along the coast of the North Mediterranean Sea in order to provide fishery-independent indices to assess the demersal species (Biagi et al., 1989; Liorzou et al., 1989; Abella and Serena, 1995; Aldebert, 1997; Ungaro et al., 1998; Kallianiotis et al., 2000). Most of these

\footnotetext{
*Received November 10, 2000. Accepted December 3, 2001.
}

experimental surveys were conducted independently in each area, without any standardization of the sampling processes. The only exception concerned a Mediterranean International Trawling survey programme (the MEDITS programme: Bertrand et al., 2000a, 2002a), carried out annually from 1994 to 2000 in several areas of the Mediterranean Sea, from Gibraltar to the Aegean Sea, using a unique standardized sampling design. In addition to the direct assessment of the commercial species, the data collected during this programme provide a 


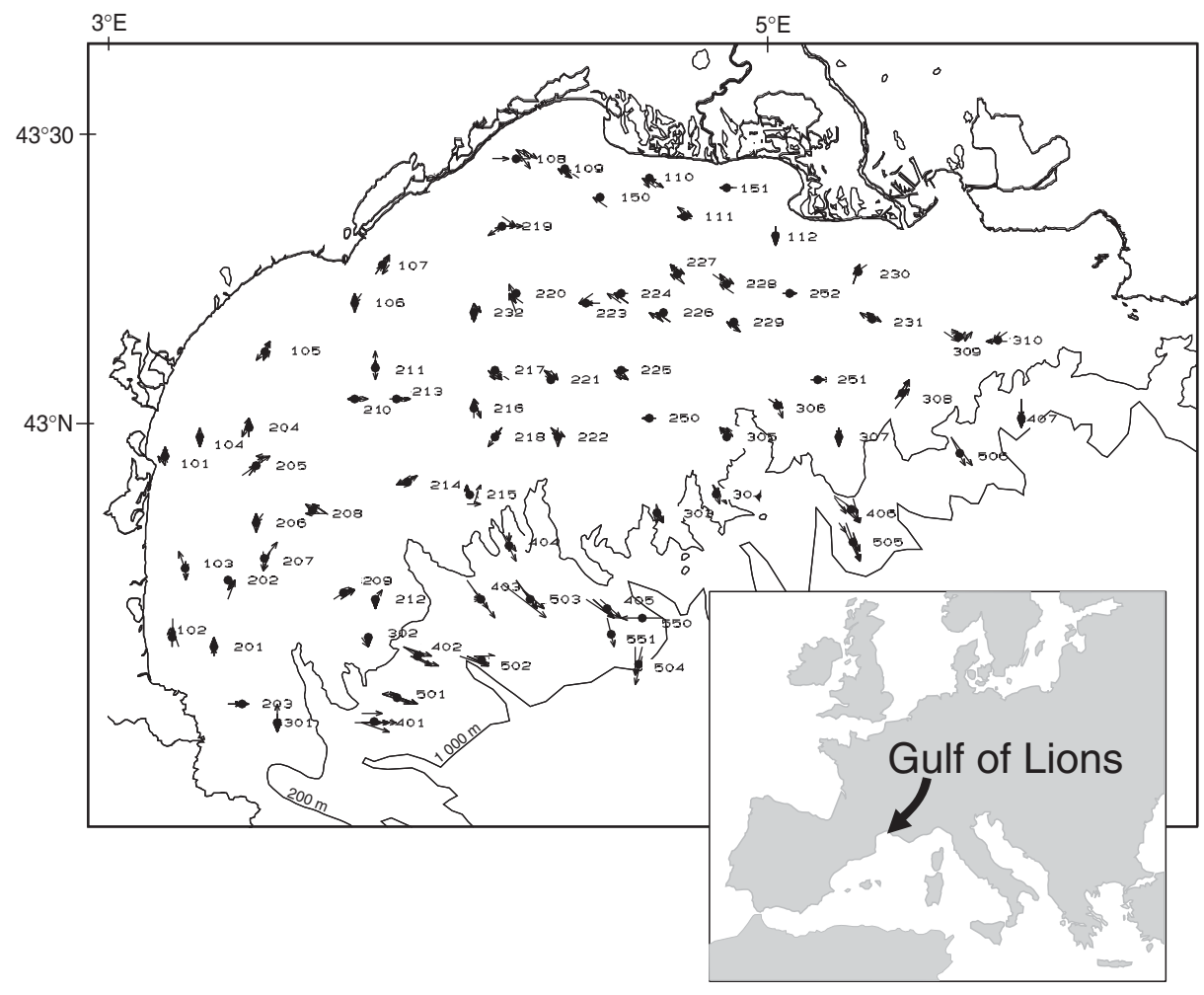

FIG. 1. - Localisation of the study site : Gulf of Lions, showing location of stations used in the sampling design. The first print of each stations' label indicates the bathymetric strata (1: from 10 to $50 \mathrm{~m}$; 2: from 50 to $100 \mathrm{~m}$; 3: from 100 to $200 \mathrm{~m}$; 4: from 200 to $500 \mathrm{~m}$; 5 : from 500 to $800 \mathrm{~m})$.

unique basis to better understand the spatio-temporal organization of the demersal assemblages at the scale of the North-Mediterranean Sea. Nevertheless, to reach such a goal, several works (Gabriel and Murawski, 1985; Mahon and Smith, 1989; Mahon et al., 1998) evidenced that it is first needed, for each of the sampled regions: (1) to define assemblages, (2) to identify their spatial distribution boundaries, and (3) to monitor their temporal evolution.

From a methodological viewpoint, these preliminary steps require, in each area, the simultaneous analysis of the data tables derived from each survey during the course of the study. Until recently, the treatment of such a three-dimensional data set (space-time-species) failed because of methodological problems (Centofanti et al., 1989; Dolédec and Chessel, 1989; Gaertner, 1997). For fishery ecology purposes, Mahon et al. (1998) pointed out the subjective aspect of traditional methodological approaches and concluded that it limited the value of works focused on this field. However, during the last decade, the development of computer tools has stimulated the creation of new statistical methods. Among them, the multitable analysis family (Escoffier and Pagès, 1994; Lavit et al., 1994; Ches- sel and Hanafi, 1996) appeared well suited to treat three-dimensional data.

In this paper, we used a recent multitable analysis specifically created to analyse the reproducibility of multivariate structures (Gaertner et al., 1998). Our goal was to show if and how this method (1) constitutes a relevant way to analyse the spatial organization of species assemblages and its pattern of changes, and (2) could be of particular interest to treat the MEDITS data both at a local and at the full MEDITS scales. In the present work, we applied this technique on MEDITS data collected between 1994 and 1999 in the Gulf of Lions (Northwest Mediterranean).

\section{MATERIAL AND METHODS}

\section{Data type and origin}

The present work was based on a set of abundance indices collected in the Gulf of Lions (Fig. 1) during the French part of the international MEDITS programme (Bertrand et al., 2000a, 2002a). We worked with six bottom trawl surveys conducted yearly at the same period (June) between 1994 and 
TABLE 1. - Description of the stratification used in the sampling design. Strata: label of strata; Limits: bathymetric limits of each strata (m); Tows: number of tows conducted in each stratum.

\begin{tabular}{ccc}
\hline Strata & Limits (m) & Tows \\
\hline 1 & $10-50$ & 14 \\
2 & $50-100$ & 35 \\
3 & $100-200$ & 10 \\
4 & $200-500$ & 7 \\
5 & $500-800$ & 8 \\
\hline
\end{tabular}

1999 by the Ressources Halieutiques Laboratory of Ifremer, Sète.

For all the surveys, a unique depth stratified random sampling design with uniform sampling fraction was used (Table 1). Location of sample units was selected randomly within each stratum. Each haul was approximately carried out at the same location from one survey to the other (Anon., 1998). A bottom trawl with a vertical opening about $2.3 \mathrm{~m}$

TABLE 2. - List of the species considered with detail on the abbreviated names used.

\begin{tabular}{|c|c|c|}
\hline Label & Scientific name & Family \\
\hline ARGY & Argentina sphyraena Linnaeus, 1758 & ARGENTINIDAE \\
\hline ARIT & Aristeus antennatus (Risso, 1816) & PANDALIIDAE \\
\hline ARNL & Arnoglossus laterna (Walbaum, 1792) & BOTHIDAE \\
\hline ARNT & Arnoglossus thori Kyle, 1913 & BOTHIDAE \\
\hline ASPI & Aspitrigla cuculus (Linnaeus, 1758) & TRIGLIDAE \\
\hline BOOP & Boops boops (Linnaeus, 1758) & SPARIDAE \\
\hline BUGL & Buglossidium luteum (Risso, 1818) & SOLEIDAE \\
\hline CALP & Synchiropus phaeton Gunther, 1861 & CALLIONYMIDAE \\
\hline CAPO & Capros aper (Linnaeus, 1758 & CAPROIDAE \\
\hline CEPO & Cepola rubescens Linnaeus, 1766 & CEPOLIDAE \\
\hline CHIM & Chimaera monstrosa (Linnaeus, 1758) & CHIMAERIDAE \\
\hline CITH & Citharus linguatula (Linnaeus 1758) & CITHARIDAE \\
\hline CLOR & Chlorophthalmus agassizi Bonaparte, 1840 & CHLOROPHTHALMIDAE \\
\hline CONG & Conger conger (Linnaeus, 1758) & CONGRIDAE \\
\hline DIPA & Diplodus annularis (Linnaeus, 1758) & SPARIDAE \\
\hline ELEC & Eledone cirrhosa (Lamarck, 1798) & OCTOPIDAE \\
\hline ELEM & Eledone moschata (Lamarck, 1799) & OCTOPIDAE \\
\hline ETMO & Etmopterus spinax (Linnaeus, 1758) & SQUALIDAE \\
\hline EUTR & Eutrigla gurnardus (Linnaeus, 1758) & TRIGLIDAE \\
\hline GADI & Gadiculus argenteus Guichenot, 1850 & GADIDAE \\
\hline GALU & Galeus melastomus Rafinesque, 1809 & SCYLIORHINIDAE \\
\hline HELI & Helicolenus dactylopterus (Delaroche, 1809) & SCORPAENIDAE \\
\hline HYME & Hymenocephalus italicus Giglioni, 1884 & MACROURIDAE \\
\hline ILLE & Illex coindetii (Verany, 1839) & TEUTHOIDEA \\
\hline LAMA & Lampanyctus crocodilus (Risso, 1810) & MYCTOPHIDAE \\
\hline LEPI & Lepidopus caudatus (Euphrasen, 1788) & TRACHIURIDAE \\
\hline LEPB & Lepidorhombus boscii (Risso, 1810) & SCOPHTALMIDAE \\
\hline LECA & Lepidotrigla cavillone (Lacepède, 1801) & TRIGLIDAE \\
\hline LEDI & Lepidotrigla dieuzeidei Audoin in Blanc and Hureau, 1973 & TRIGLIDAE \\
\hline LOLI & Loligo vulgaris Lamarck, 1798 & LOLIGINIDAE \\
\hline LOPB & Lophius budegassa Spinola, 1807 & LOPHIIDAE \\
\hline LOPP & Lophius piscatorius Linnaeus, 1758 & LOPHIIDAE \\
\hline MERL & Merluccius merluccius (Linnaeus, 1758) & MERLUCIIDAE \\
\hline MICM & Micromesistius poutassou (Risso, 1826) & GADIDAE \\
\hline MICU & Microchirus variegatus (Donovan, 1802) & SOLEIDAE \\
\hline MULB & Mullus barbatus Linnaeus, 1758 & MULLIDAE \\
\hline MULS & Mullus surmuletus Linnaeus, 1758 & MULLIDAE \\
\hline NEPR & Nephrops norvegicus (Linnaeus, 1758) & NEPHROPIDAE \\
\hline OCTO & Octopus vulgaris Cuvier, 1797 & OCTOPODIDAE \\
\hline PAGA & Pagellus acarne (Risso, 1826) & SPARIDAE \\
\hline PAGB & Pagellus bogaraveo (Brunnich, 1768) & SPARIDAE \\
\hline PAGY & Pagellus erythrinus (Linnaeus, 1758) & SPARIDAE \\
\hline PHYI & Phycis blennoides (Brünnich, 1768) & GADIDAE \\
\hline PLEM & Plesionika martia (A. Milne Edwards, 1883) & PANDALIDAE \\
\hline RAJC & Raja clavata Linnaeus, 1758 & RAJIDAE \\
\hline ROSS & Rossia macrosoma (Delle Chiaje, 1829) & SEPIOLIDAE \\
\hline SCON & Scorpaena notata Rafinesque, 1810 & SCORPAENIDAE \\
\hline SCYO & Scyliorhinus canicula (Linnaeus, 1758) & SCYLIORHINIDAE \\
\hline SEPE & Sepia elegans Blainville , 1827 & SEPIIDAE \\
\hline SEPO & Sepia orbignyana Ferussac, 1826 & SEPIIDAE \\
\hline SERC & Serranus cabrilla (Linnaeus, 1758) & SERRANIDAE \\
\hline SERH & Serranus hepatus (Linnaeus, 1766) & SERRANIDAE \\
\hline SOLE & Solea vulgaris (Quensel, 1806) & SOLEIDAE \\
\hline SOLO & Solenocera membranacea (Risso, 1816) & SOLENOCERIDAE \\
\hline SPIC & Spicara maena (Linnaeus, 1758) & CENTRACANTHIDAE \\
\hline TODI & Todaropsis eblanae (Ball, 1841) & TEUTHOIDEA \\
\hline TRAH & Trachinus draco Linnaeus, 1758 & TRACHINIDAE \\
\hline TRIY & Trigla lyra Linnaeus, 1758 & TRIGLIDAE \\
\hline TRIS & Trisopterus capelanus minutus (Lacépede, 1800) & GADIDAE \\
\hline TRIP & Trigloporus lastoviza (Bonnaterre, 1788) & TRIGLIDAE \\
\hline URAN & Uranoscopus scaber Linnaeus, 1758 & URANOSCOPIDAE \\
\hline ZEUS & Zeus faber Linnaeus, 1758 & ZEIDAE \\
\hline
\end{tabular}


was used. Tows were $30 \mathrm{~min}$ in duration when the depth was between 10 and $200 \mathrm{~m}$, and $60 \mathrm{~min}$ when it was deeper (from 200 to $800 \mathrm{~m}$ ). Sixty-nine of the species caught during the five surveys (Table 2) were sufficiently abundant to be included in the analysis (i.e. they were present in more than $5 \%$ of the tows). For each tow, the densities in number of individuals were expressed for a same surface unit (hectare). The data were log-transformed before conducting the analysis to minimise the dominant effect of exceptional catches.

\section{Data analysis}

The temporal monitoring of the spatial organization of the demersal assemblages during the course of the study required the combined analysis of the data tables issued from each survey. For that purpose, we carried out the STATIS-CoA multitable method (Gaertner et al., 1998), which couples STATIS method (Lavit et al., 1994), and Correspondence analysis (Hill, 1973).

The first stage of the CoA version of STATIS consists in calculating a matrix of scalar products between variables (i.e. species in the present case) for each table (i.e. trawl survey) in order to standardize the dimensions of the tables. This step makes it then possible to compare all the tables by calculation of a matrix of scalar products between tables (Robert and Escouffier, 1976). The diagonalization of this matrix provides eigenvectors. The $\mathrm{k}$ coefficients of the first eigenvector are used to weight the $\mathrm{k}$ tables in the calculation of a "compromise table". This weighting allows the construction of a compromise table that contains the common part of the studied structures. In other words, the compromise table is a linear combination of the $\mathrm{k}$ initial tables (i.e. the six surveys in the present case) calculated with the aim of constructing a mean table of maximum inertia. Thus, in the construction of the compromise table a greater importance is given to the tables that have similar structures and a limited one to the other tables. The analysis $(\mathrm{CoA})$ of the compromise table defines axes and components that express the common part of the structures studied (i.e. the common part of the spatial organisation patterns of demersal assemblages during the course of the study).

Independently, a separate Correspondence Analysis of each of the six surveys was carried out. This step allows the projection of the first axes of the separate analyses of each survey onto the first axes of the compromise table. This representation
TABLE 3. - Description of the structure defined for each survey. Weight: contribution of each table in the construction of the com promise; $\mathrm{Cos}^{2}$ : fit of each table to the compromise.

\begin{tabular}{lll}
\hline & Weight & Cos $^{2}$ \\
\hline 1994 & 0.40 & 0.79 \\
1995 & 0.41 & 0.82 \\
1996 & 0.42 & 0.87 \\
1997 & 0.41 & 0.80 \\
1998 & 0.41 & 0.82 \\
1999 & 0.39 & 0.72 \\
\hline
\end{tabular}

indicates how much the main structures of each initial table are taken into account in the compromise (Lavit et al., 1994). In the present study, it gives a better insight into the temporal stability of the main organisational patterns. In addition, the projection of the $\mathrm{k}$ initial tables onto the compromise allows us to draw the trajectories that represent the temporal variations of each species around the common structure. Technically, this involves projecting onto the axes of the compromise table, the factorial scores that each species obtains in each of the separate tables.

In comparison with the classical method of STATIS, the CoA version used in the present work is specifically suited to analyse the spatio-temporal organisation of assemblages in term of species composition (Gaertner et al., 1998) and it allows the optimal plot of temporal species trajectories (Dolédec and Chessel, 1989). This CoA version of STATIS may currently be performed with the ADE4 software (Thioulouse et al., 1996). This software is freely available at the following address: http://pbil.univ-lyon1.fr/ADE-4.html

\section{RESULTS}

The first results given by the use of STATIS-CoA (Table 3) showed that the contributions of the different surveys to the construction of the compromise table are similar (weights from 0.39 to 0.41 ). So, each of the six surveys played a similar role in the constitution of the STATIS compromise table. Moreover, the fit of each of the tables to the compromise table $\left(\mathrm{Cos}^{2}\right)$ was homogeneous. The weakest values observed for $1999\left(\mathrm{Cos}^{2}=0.72\right)$, indicated that the structure of this survey was less well-taken into account in the compromise table. However, the high similarity between the projections of the first and the second axes of the separate CoAs of each of the six surveys with the first two axes of the compromise 


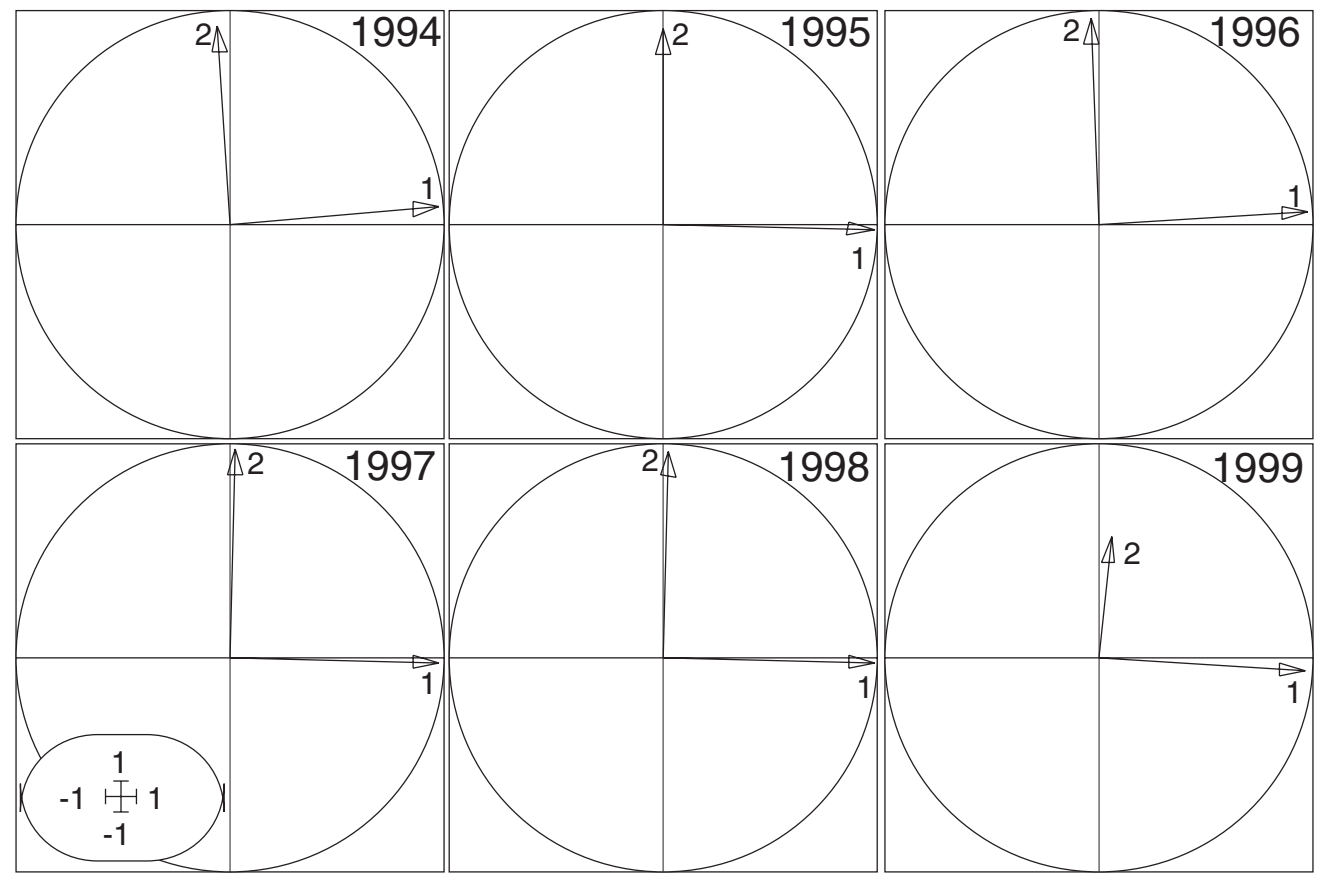

FIG. 2. - Projection of the first two factorial axes of the separate Correspondence Analysis of each survey (arrows) on the two first factorial axes of the STATIS-CoA compromise (axis 1: horizontal; axis 2: vertical).

table showed that the two main organisational directions expressed in the compromise table are common to each of the six surveys (Fig. 2). The weakest fit of 1999 to the compromise appeared only on the second axis of the separate Correspondence analysis. In short, these preliminary results suggested the existence of a strong inter-annual stability in the spatial organisation of the demersal assemblages in the Gulf of Lions during the period studied, but with a limited variability during the 1999 survey.

The first two axes of the compromise of STATIS-CoA accounted for $26 \%$ and $11 \%$ of the total variability, respectively. The projection of the samples' factorial scores onto the first two axes of the compromise provided a representation of the stable part of the main spatial structures (Fig. 3). It showed a pattern of organisation based on a coastopen sea gradient, which can be divided into three main regions, each of them being characterised by specific assemblages. Species of the coastal area (stratum 1, between 10 and $50 \mathrm{~m}$ depth) and of the continental shelf (strata 2 and 3 , between 50 and $200 \mathrm{~m}$ depth) could be associated in a first assemblage. The upper slope (stratum 4, from 200 to 500 $\mathrm{m})$ constituted a second homogeneous area in term of species composition, while the deeper slope (stratum 5, from 500 to $800 \mathrm{~m}$ ) contained a third assemblage. A very sharp discrimination of the spatial boundaries of these three assemblages of species was found (Fig. 3a).

Moreover, we can notice that each station that belonged to one of the bathymetric regions was generally localised with stations of the same bathymetric region during the different surveys (Fig. 3b). This result confirmed the strong reproducibility of the spatial structuring of the studied assemblages. However, an element of variation appeared during the survey conducted in 1999. It mainly affected some of the stations of stratum 5 which were then reallocated with stations of stratum 4 .

Figure 4 details the organisation pattern of all the species along the bathymetric gradient. It gives a typology of the species with reference to the common pattern observed in the course of the six surveys. A first assemblage linked fishes (Diplodus annularis, Buglossidium luteum, Pagellus erythrinus, Boops boops, Solea vulgaris, Uranoscopus scaber) and cephalopods (Loligo vulgaris, Octopus vulgaris) only caught in the coastal area (stratum 1). Fish species such as Mullus barbatus, Pagellus acarne, Lophius piscatorius, Lophius budegassa, Zeus faber, Merluccius merluccius, Mullus surmuletus, Lepidotrigla dieuzeidei, Argentina sphyraena, Scyliorhinus canicula and the cephalopod Illex coindetii found in the continental shelf also belonged to this assemblage. 
(A)
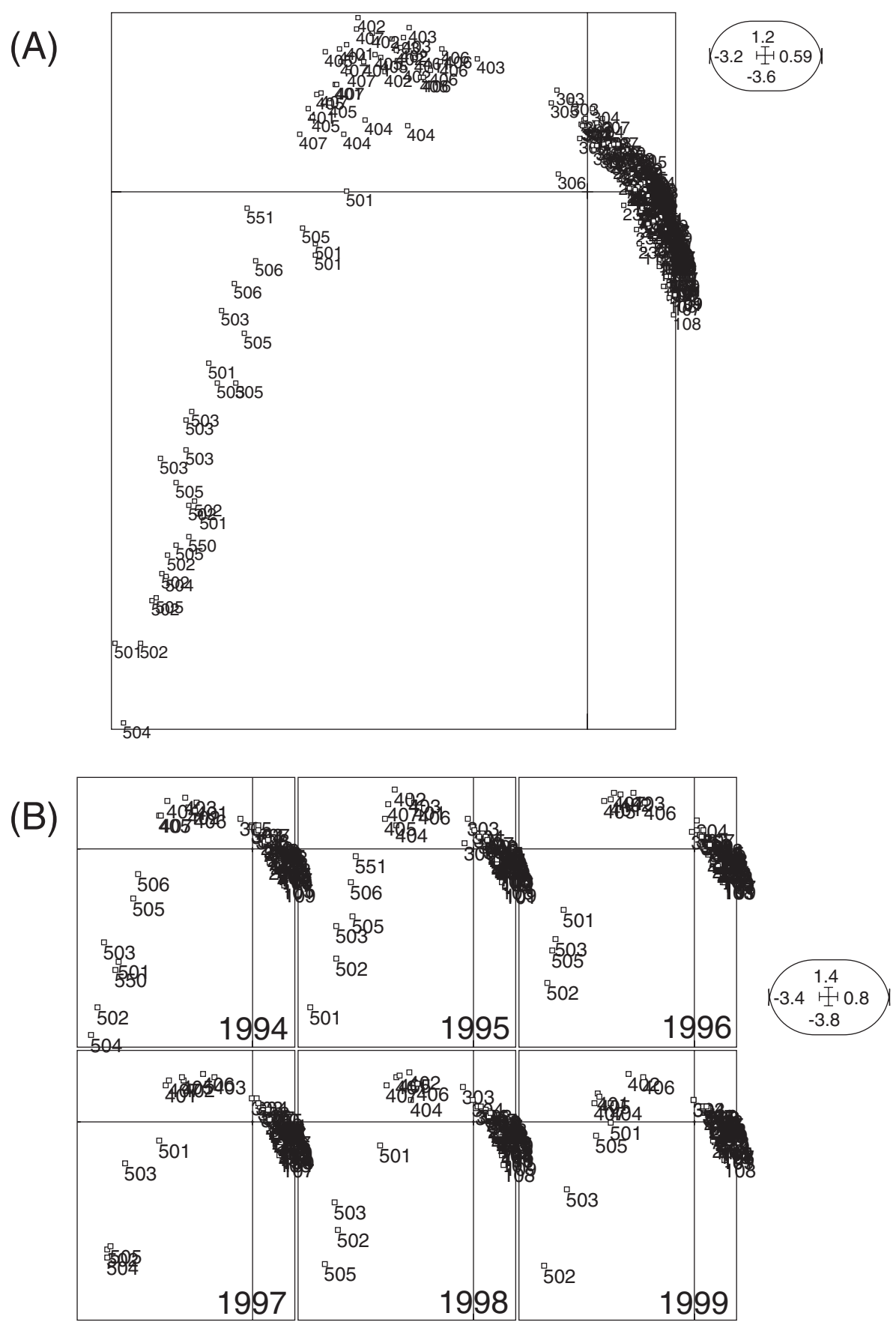

FIG. 3. - Projection of the factorial scores of the stations (A) for the whole studied period and (B) for each separated survey on the two first factorial axes of the STATIS-CoA compromise (axis 1: horizontal; axis 2: vertical). Stations labelled as in Fig. 1.

The upper slope assemblage was characterised by fishes such as Lepidorhombus boscii, Micromesistius poutassou, Trigla lyra, Gadiculus argenteus, Phycis blennoides, Helicolenus dactylopterus and by a crustacean: Nephrops norvegicus. Other fish species such as Galeus melastomus, Chimaera monstrosa, Etmopterus spinax, Trachyrhynchus trachyrhynchus and crustaceans (Aristeus antennatus and Plesionika martia) belonged to the deeper slope assemblage. At the scale of the study, our results showed that this bathymetric gradient was associated with a species-richness gradient, which decreased from the coast to the deeper slope.

Finally, the species' trajectories allowed to analyse the variability of the position of each taxon around the common structure (Fig. 5). However, the strong overlap of the ranges of distribution observed complicated the analysis of the species trajectories. 


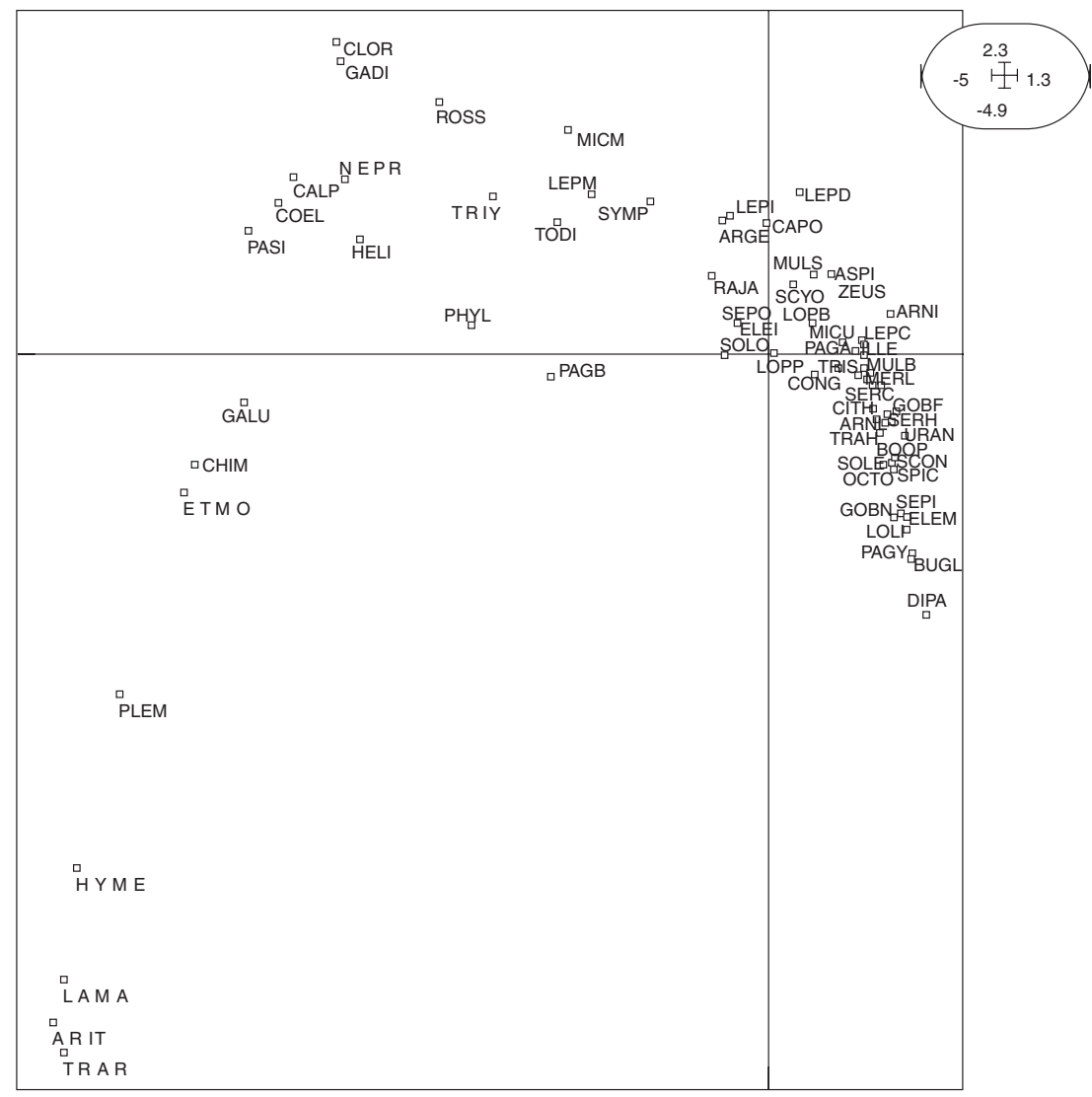

FIG. 4. - Projection of the species on the first factorial plane of STATIS-CoA compromise (axis 1: horizontal; axis 2: vertical). Species codes as in Table 1.

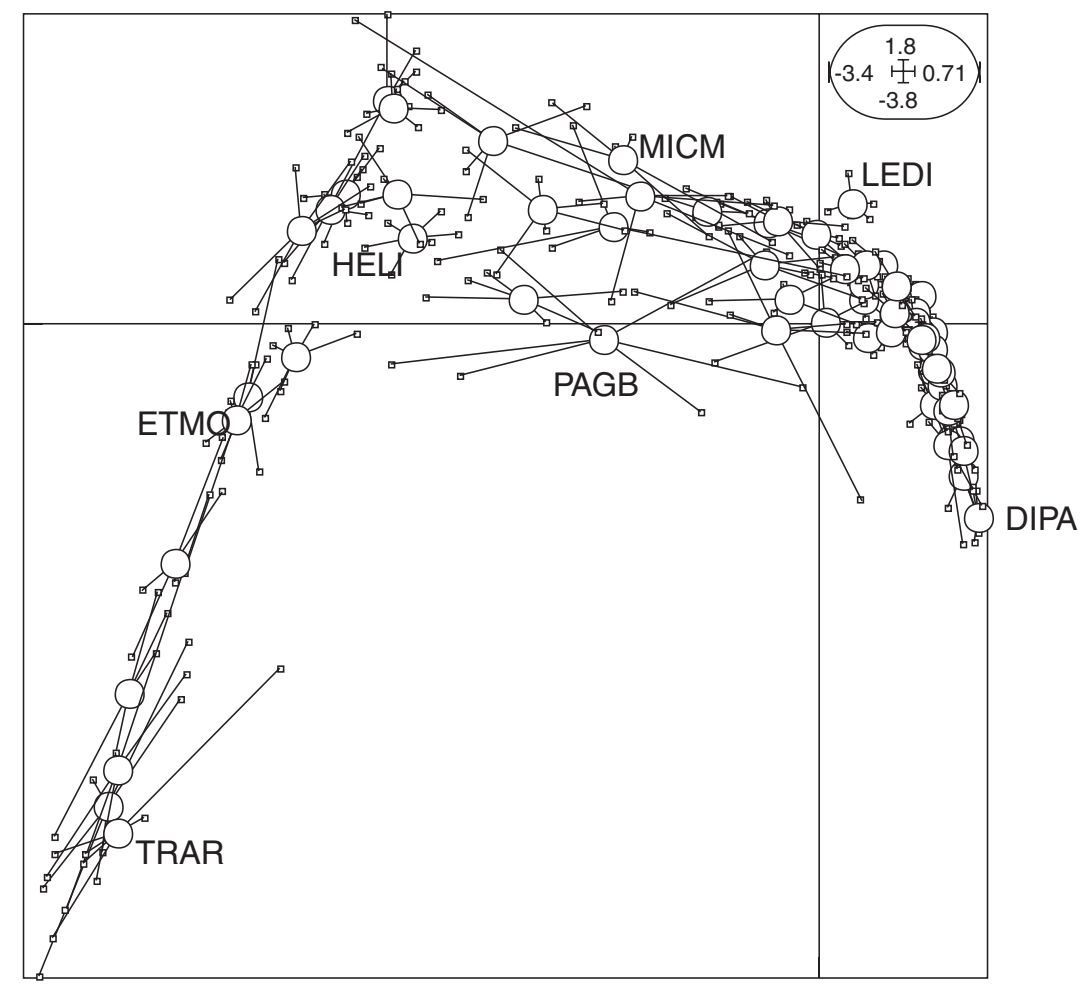

FIG. 5. - Projection of the species' trajectories on the first factorial plane of STATIS-CoA compromise (axis 1: horizontal; axis 2: vertical). The position of a species in each survey $(\square)$ is related to its position in the compromise (○). Species codes as in Table 1. 


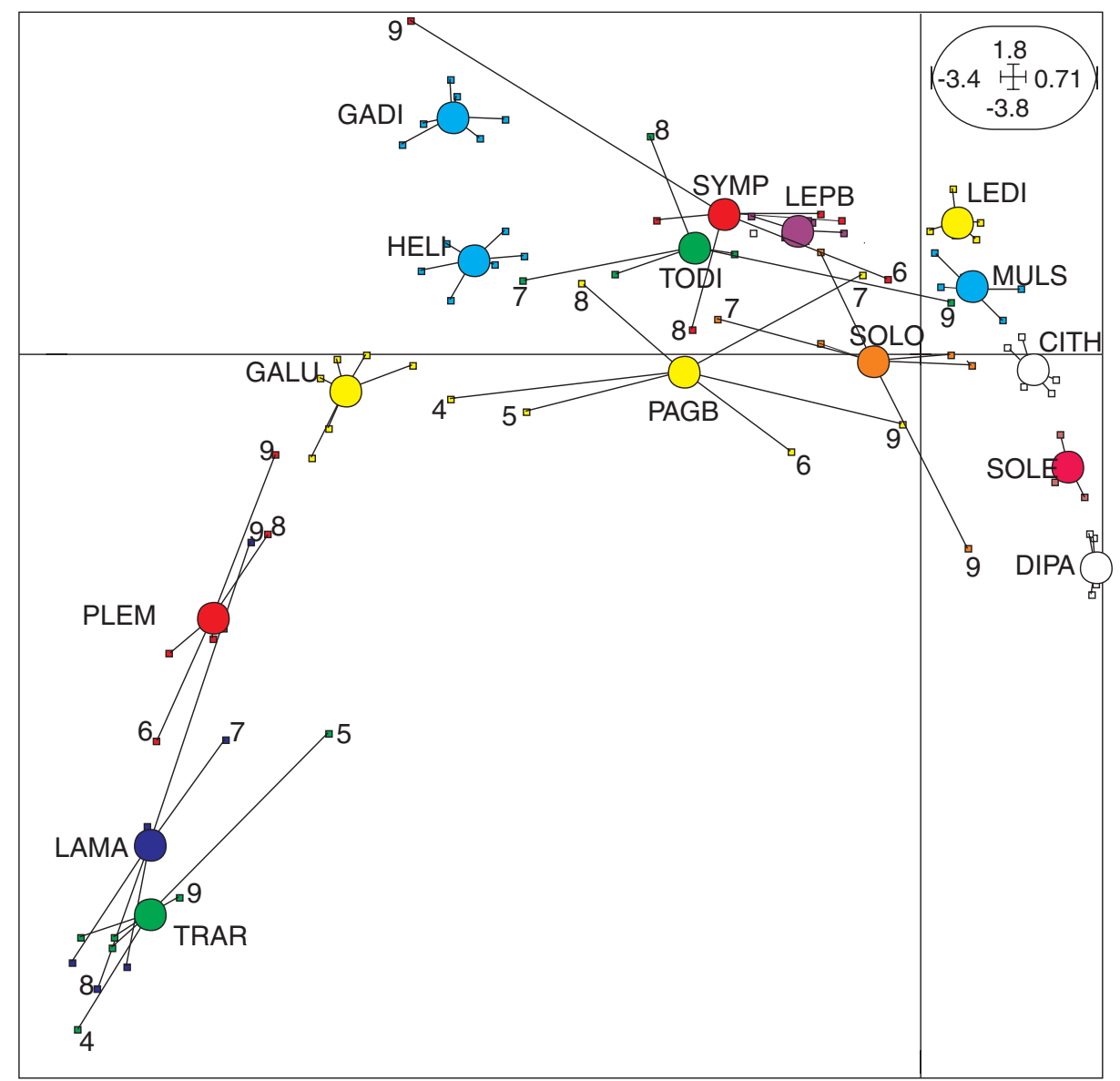

FIG. 6. - Detail of the projection of the trajectories of some characteristic species on the first factorial plane of STATIS-CoA compromise (axis 1: horizontal; axis 2: vertical). Species codes as in Table 1. The code used for the trajectories refers to the corresponding survey (4: 1994; 5: 1995; 6: 1996; 7: 1997; 8: 1998; 9: 1999).

Consequently, the projection of only a few representative species of each assemblage was provided to illustrate their temporal variations (Fig. 6). A generally weak variation of species around their reference position may be observed in the area that spread between the coast and the continental shelf (strata 1 to 3). This was also the case for some species of stratum 4 (Lepidorhombus boscii, Gadiculus argenteus, Helicolenus dactylopterus) and stratum 5 (Galeus melastomus and Hymenocephalus italicus). Nevertheless, some other species of these two latter assemblages exhibited a strong variability in relation to their reference position (see Pagellus bogaraveo, Solenocera membranacea, Todaropsis eblanae, Chimaera monstrosa, Plesionika martia, Lampanyctus crocodilus and Aristeus antennatus). Among them, we can note that the strong trajectories of $S$. membranacea, T. eblanae, C. monstrosa and L. crocodilus mainly occurred during the survey conducted in 1999.

\section{DISCUSSION}

In the present study, we have shown that the demersal assemblages of the Gulf of Lions were mainly organised along a bathymetric gradient. At the scale of the Gulf, we showed that this gradient can be split into three areas: 1) the coastal region and the continental shelf (10 to $200 \mathrm{~m}$ depth), 2) the upper slope (200 to $500 \mathrm{~m}$ ) and 3) the deeper slope (500 to $800 \mathrm{~m}$ ). Associated to this bathymetric structuring we found a species-richness gradient, which decreased from the coast to the upper slope. Our analysis showed that this spatial organisation pattern was highly persistent during the course of the study. However, a few species caught in the slope area exhibited a strong variability of their spatial distribution mainly during the 1999 survey.

The preponderance of depth on the spatial organisation of demersal assemblages has been common- 
ly reported both in the study site (Maurin, 1968; Gaertner et al., 1998) and in the world's oceans (Fager and Longhurst, 1968; Mahon and Smith, 1989; Bianchi, 1991; Gordon and Bergstad, 1992; Weinberg, 1994; Fujita et al., 1995; Gomes et al., 1995; McClatchie et al., 1997; Mahon et al., 1998). Nevertheless, identification of the factors really responsible for the structuring of species along this gradient is difficult. In the literature, despite the diversity of the field experiments, some factors such as physical and chemical characteristics of the water (Fager and Longhurst, 1968; Mahon and Smith, 1989; Loneragan and Potter, 1990; Bianchi, 1992; Rakocinski et al., 1992; Perry et al., 1994) or other habitat features (Bianchi, 1992; Jackson and Harvey, 1992; Auster et al., 1995) were often described to influence the organisational patterns of groundfish assemblages. In the Gulf of Lions, a recent analysis, from a series of bottom trawl surveys carried out between 1985 and 1992 (the CHALIST surveys), suggested that demersal assemblages were partly linked with sediment type and composition of macrofauna communities (Gaertner et al., 1999). In the present study, the lack of environmental data prevented us from either validating or completing our knowledge on this topic. This latter point highlights a present limitation of numerous experimental resources assessment programmes to progress in that direction due to the frequent weakness of effort dedicated to obtaining information on environmental descriptors (Perry et al., 1994). The recent improvement of technological devices (satellite sensors, cameras, multiparameter probes, etc.) coupled with trawling could help to reverse this trend and thus might provide multicompartment data bases whose analysis is now possible owing to the new available statistical developments (Gaertner et al., 1999; Mazouni et al., 2001).

The strong stability of organisational pattern observed in the present study agrees with the conclusions of other works on demersal assemblages (Colcovocoresses and Musick, 1984; Mahon and Smith, 1989; Gabriel, 1992; Gomes et al., 1995; Gaertner et al., 1998). Nevertheless, in strongly exploited ecosystems, stability periods can be followed by periods of great changes in species composition (see Gomes et al., 1995). In numerous cases, these variations have been attributed to the direct and indirect effect of intensive trawling (Hutchings, 1990; Harris and Poiner, 1991; Thrush et al., 1995). In the Gulf of Lions, the fishing activity - notably by the trawling fleet - is heavy. Never- theless, the main changes occurred since the 1970's (Meuriot et al., 1987; Taquet et al., 1997) and no major change in species composition eventually linked with fishery has been identified from our study. These preliminary results could suggest a weak influence of trawling on the composition of the demersal assemblages in the Gulf of Lions. However, the short length of our study (six years) did not permit us to really conclude on this point. Actually, available information on strong changes in exploited population abundance in this area (mainly on species belonging to the Selacians guild) have been obtained from longer series of data (Aldebert, 1997; Bertrand et al., 2000b). So far, only the continuation of the MEDITS surveys over a long period (even at a wider temporal scale) would allow a deeper analysis of the effects of trawling on assemblages' organisation.

The only element of variability observed during the studied period concerned the slope area in 1999. A part of this observed variability could be linked to the sampling. Indeed, by using a system which controls the trawl geometry (a Scanmar device), Bertrand et al. (2002b) pointed out the potential influence of the variability of trawl performances on the catches, mainly in the slope area. At the present state of knowledge, it is not possible to quantify the respective part of the observed variability linked to sampling and the one corresponding to real changes in assemblages' organisation. Nevertheless, these results led us to suggest some improvements in the sampling methodology for future MEDITS surveys. First, it pointed out the necessity of systematically using underwater instruments (such as Scanmar device) to control fishing operations, and to stabilise trawl performances. Secondly, it could incite to adjust the future sampling effort to the observed variability. Nevertheless, the management of this kind of adaptation may be difficult taking into account the diverse objectives of the survey.

From an experimental viewpoint, the comparison of our results with previous works conducted in the same area leads to several comments. The bathymetric gradient estimated from the results of the surveys conducted in the Gulf of Lions between 1994 and 1999 (present analysis of the MEDITS data) was similar to the pattern previously observed on the basis of the surveys performed between 1985 and 1992 (CHALIST surveys: Gaertner, 1997; Gaertner et al., 1998). However, in these previous works, the split of the species into three assemblages was not so clear and the bathymetric boundaries were different. 
Moreover, 69 species were taken into account in the present analyses, whereas using the same selection criteria, only 45 were considered in the analyses based on the results of the CHALIST surveys (42 species are common to the two periods). Differences in the sampling performances (different vessels, gear and handling protocols) may probably explain a great part of these discrepancies.

In addition, contrary to the MEDITS programme, the 500 to $800 \mathrm{~m}$ depth stratum was not sampled during the CHALIST programme. As a consequence, the global scale of observation was different in the two programmes. This problem has been highlighted by several authors who showed, both in marine and terrestrial ecosystems, that community structuring is a hierarchical concept strongly linked to the scales of observation (Connell and Sousa, 1983; Wiens, 1986; Rahel, 1990). More generally, this pointed out the importance of the scales in the perception of the factors acting on the community organisation (Ricklefs, 1987; Wiens, 1989), and that there is not only one relevant scale of observation (Levin, 1992). In community ecology, numerous controversies on the determinism of assemblages were only linked to the lack of homogeneity between the scales used in the comparative studies (Wiens, 1989; Rahel, 1990; Levin, 1992). Thus, in the context of the MEDITS programme, in addition to the need to standardise all the technical elements of the sampling designs (vessel, gear, net mesh, etc.), it appears essential to use common scales of observation in order to develop inter-regional comparison approaches.

From a methodological point of view, the two approaches most commonly used for analysing the spatio-temporal organisation of communities are based on clustering or simple factorial analyses. A first traditional approach is turned to comparative reading of typologies obtained separately for each of the surveys. It consists in roughly estimating the graphic similarities between the structures observed independently for each survey (Gabriel and Tyler, 1980; Overholtz and Tyler, 1985; Mahon and Smith, 1989; Gabriel, 1992; Rakocinski et al., 1992; Fujita et al., 1995; Mahon et al., 1998). This procedure runs into difficulties whenever the tables to be compared are too numerous or extensive (Amanieu et al., 1981; Gaertner, 1997). The second traditional approach involves carrying out multivariate analysis after pooling in a single table the data from different surveys. This method, used for the analysis of demersal fish organization in numerous regions in the world (Mahon, 1985; Roel, 1987; Macpherson and Gordoa, 1992; Weinberg, 1994) can however result in a confusing mixture of spatial and temporal effects (Centofanti et al., 1989; Gaertner, 1997).

In this context, multitable analyses, such as the one proposed by the STATIS-CoA, offer an original solution to solve these problems. Indeed, specifically created to split the stable and variable parts of the spatial organisation of communities, this approach proposes a rigorous theoretical framework for the simultaneous analysis of several data tables (see Gaertner et al., 1998). Consequently, multitable analyses circumvent the difficulties linked with the subjective aspects of the first traditional approach and the confusing interaction between spatial and temporal scales inherent to the second approach.

In conclusion, in the prospect of MEDITS developments, approaches using a multitable method should help the analysis of several concrete questions:

- At a local scale, (i.e. for each area surveyed by the programme), it can allow for the characterisation of species assemblages, to identify their spatial distribution boundaries and to monitor their temporal evolution. The interest of this knowledge is double. Firstly, these findings are relevant to define spatial or ecosystem units in order to provide background for fisheries management (Tyler et al., 1982; Gabriel and Murawski, 1985; Biagi et al., 1989; Mahon et al., 1998). Secondly, it constitutes the obligatory starting point before developing inter-regional comparative approaches (Gaertner, 1997).

- At a more global scale, and on the basis of the previous results, the method could be carried out in an original way to simultaneously compare the spatial organisation of demersal assemblages in several regions. Applying multitable analysis for this purpose should help to improve our understanding on the determinism of demersal assemblages at the scale of the north of the Mediterranean Sea.

\section{REFERENCES}

Abella, A. and F. Serena. - 1995. Definition of the groundfish assemblages caught off the Tuscanian coast for fisheries management purposes. Rapp. Comm. int. Mer Médit., 34: 235-241.

Aldebert, Y. - 1997. Demersal resources of the Gulf of Lions (Northwestern Mediterranean). Impact of exploitation on fish diversity. Vie Mil., 47: 275-284.

Amanieu, A., O. Guelorget and J. Nouguier-Soule. - 1981. Analyse de la diversité de la macrofaune benthique d'une lagune littorale Méditerranéenne. Vie Mil., 31(3-4): 303-312.

Anon. - 1998. Campagne internationale de chalutage démersal en Méditerranée (MEDITS): manuel des protocoles. Biol. Mar. Medit. 5: 515-572. 
Auster, P.J., R.J. Malatesta and S.C. La Rosa. - 1995. Patterns of microhabitat utilization by mobile megafauna on the southern New England (USA) continental shelf and slope. Mar. Ecol. Prog. Ser., 127: 77-85.

Bertrand, J.A., Y. Aldebert and A. Souplet. - 2000b. Temporal variability of demersal species in the Gulf of Lions from trawl surveys (1983-1997). In: J.A. Bertrand and G. Relini (eds.), Demersal resources in the Mediterranean, Proceedings of the Symposium held in Pisa, 18-21 March 1998, Actes de Colloques 26, pp. 153-164. IFREMER, Plouzané.

Bertrand, J.A., L. Gil de Sola, C. Papaconstantinou, G. Relini and A. Souplet. - 2000a. An international bottom trawl survey in the Mediterranean: the MEDITS programme. In: J.A. Bertrand and G. Relini (eds.), Demersal resources in the Mediterranean, Proceedings of the Symposium held in Pisa, 18-21 March 1998, Actes de Colloques 26, pp. 76-93. IFREMER, Plouzané.

Bertrand, J., L. Gil de Sola, C. Papaconstantinou, G. Relini and A. Souplet. - 2002a. The general specifications of the MEDITS surveys. Sci. Mar., 66 (Suppl. 2): 9-17.

Bertrand, J.A., I. Leonori, P.Y. Dremière and G. Cosimi.- 2002 b. Depth trajectory and performance of a trawl used for an international bottom trawl survey in the Mediterranean. Sci. Mar., 66 (Suppl. 2): 169-182.

Biagi, F., S. De Ranieri, M. Mori, P. Sartor and M. Sbrana. - 1989 Preliminary analysis of demersal fish assemblages in the northern Tyrrhenian sea. Nova Thalassia, 10: 391-398.

Bianchi, G. - 1991. Demersal assemblages of the continental shelf and slope edge between the gulf of Tehuantepec (Mexico) and the gulf of Papagayo (Costa Rica). Mar. Ecol. Prog. Ser., 73: 121-140.

Bianchi, G. - 1992. Demersal assemblages of the continental shelf and upper slope of Angola. Mar. Ecol. Prog. Ser., 81: 101-120.

Centofanti, M., D. Chessel and S. Doledec. - 1989. Stabilité d'une structure spatiale et compromis d'une analyse statistique multitableaux: Application à la physico-chimie d'un lac réservoir. Rev. Sciences Eau, 2: 71-93.

Chessel, D. and H. Hanafi. - 1996. Analyses de la co-inertie de Knuages de points. Rev. Stat. appl., 44: 35-60.

Colcovocoresses, J.A. and J.A. Musick. - 1984. Species association and community composition of middle Atlantic bight continental shelf demersal fishes. Fish. Bull., 82: 295-313.

Connell, H.J. and W.P. Sousa. - 1983. On the evidence needed to judge ecological stability of persistence. Am. Nat., 121: 789-825.

Dolédec, S. and D. Chessel. - 1989. Rythmes saisonniers et composantes stationnelles en milieu aquatique. II) Prise en compte et élimination d'effets dans un tableau faunistique. Acta Oecol. Gener., 10: 207-232.

Escoffier, B. and J. Pagès. - 1994. Multiple factor analysis (AFMULT package). Comput. Stat. Data Anal., 18: 121-140.

Fager, E.W. and A.R. Longhurst. - 1968. Recurrent group analysis of species assemblages of demersal fish in the Gulf of Guinea J. Fish. Res. Bd. Canada, 25: 1405-1421.

Fujita, T., I. Tadashi and Y. Ishito. - 1995. Depth-gradient structure on the demersal fish community on the continental shelf and slope off Sendai Bay, Japan. Mar. Ecol. Prog. Ser., 118: 13-23.

Gabriel, W.L. - 1992. Persistence of demersal fish assemblages between cape Hatteras and Nova Scotia, northwest Atlantic. $J$. Northw. Atl. Fish. Sci., 14: 29-46.

Gabriel, W.L. and S.A. Murawski. - 1985. The use of cluster analysis in identification and description of multispecies system. In: R. Mahon (ed.), Toward the inclusion of fishery interactions in management advice. Can. Tech. Rep. Fish. Aquat. Sci., 1347: 112-117.

Gabriel, W.L. and A.V. Tyler. - 1980. Preliminary analysis of Pacific coast demersal fish assemblages. Mar. Fish. Rev., 1980: 83-88.

Gaertner, J.C. - 1997. Organisation des assemblages démersaux dans le golfe du Lion: structures spatiales et stabilité temporelle. $\mathrm{PhD}$ thesis, Univ. Aix-Marseille II.

Gaertner, J.C., D. Chessel and J. Bertrand. - 1998. Stability of spatial structures of demersal assemblages: a new approach. Aquat Living Resour., 11: 75-85.

Gaertner, J.C., N. Mazouni, R. Sabatier and B. Millet. - 1999. Spatial structure and habitat associations of demersal assemblages in the Gulf of Lions: a multicompartment approach. Mar. Biol., 135: 199-208.

Gomes, M.C., R.L. Haedrich and M.G. Villagarcia. - 1995. Spatial and temporal changes in the groundfish assemblages on the
North-east Newfoundland/ Labrador shelf, north-west Atlantic, 1978-1991. Fish. Oceanogr., 4: 85-101.

Gordon, J.M. and O.A. Bergstad. - 1992. Species composition of demersal fish in the Rockall Trough, North Eastern Atlantic, as determined by different travels. J. mar. biol. Ass. UK., 72: 213-230.

Harris, A.N. and I.R. Poiner. - 1991. Changes in species composition of demersal fish fauna of southeast gulf of Carpentaria, Australia, after 20 years of fishing. Mar. Biol., 111: 503-519.

Hill, M.O. - 1973. Reciprocal averaging : an eigenvector method of ordination. J. Ecology, 61: 237-249.

Hutchings, P. - 1990. Review of the effects of trawling on macrobenthic epifaunal communities. Aust. J. mar. fresh. Res., 41: 111-120.

Jackson, D.A. and H.H. Harvey. - 1992. Fish and benthic invertebrates: community concordance and community-environment relationships. Can. J. Aquat. Fish. Sci., 50: 2641-2651.

Kallianiotis, A., K. Sophronidis, P. Vidoris and A. Tselepides. 2000. Demersal fish and megafaunal assemblages on the Cretan continental shelf and slope (NE Mediterranean): seasonal variation in species density, biomass and diversity. Prog. Oceanogr., 46: 429-455.

Lavit, C., Y. Escoufier, R. Sabatier and P. Traissac. - 1994. The ACT (Statis method). Comput. Stat. Data Anal., 18: 97-119.

Levin, S.A. - 1992. The problem of pattern and scale in Ecology. Ecology, 73: 1943-1967.

Liorzou, B., A. Campillo and J.-L. Bigot. - 1989. Estimation de l'abondance relative de Lophius budegassa du golfe du Lion à partir des campagnes de chalutage (1983-1987). Bull. Soc. Zool. France, 114(4): 101-112.

Loneragan, N.R. and I.C. Potter. - 1990. Factors influencing community structure and distribution of different life-cycle categories of fishes in shallow waters of a large Australian estuary. Mar. Biol., 106: 25-37.

Macpherson, E. and A. Gordoa. - 1992. Trends in the demersal fish community of Namibia from 1983 to 1990. S. Afr. J. mar. Sci., 12: 635-649.

Mahon, R. - 1985. Groundfish assemblages on the Scotian shelf. In: R. Mahon (ed.), Toward the inclusion of fishery interactions in management advice. Can. Tech. Rep. Fish. Aquat. Sci., 1347: $153-162$.

Mahon, R., S.K. Brown, K.C.T. Zwanenburg, D.B. Atkinson, K.R. Buja, L. Claflin, G.D. Howell, M.E. Monaco, R.N. O’Boyle and M. Sinclair. - 1998. Assemblages and biogeography of demersal fishes of the east coast of North America. Can. J. Fish. Aquat. Sci., 55: 1704-1738.

Mahon, R. and R.W. Smith. - 1989. Demersal fish assemblages on the Scotian shelf, northwest Atlantic: spatial distribution and persistence. Can. J. Aquat. Fish. Sci., 46: 134-152.

Maurin, C. - 1968. Ecologie ichthyologique des fonds chalutables atlantiques (de la baie ibéro-marocaine à la Mauritanie) et de la Méditerranée occidentale. Rev. Trav. Inst. Pêches marit., 32: $5-147$

Mazouni, N., J.C. Gaertner and J.M. Deslous-Paoli. - 2001. Composition of biofouling communities on suspended oyster-cultures: an in situ study of their interactions with the water column. Mar. Ecol. Prog. Ser., 214: 93-102.

McClatchie, S., R.B. Millar, F. Webster, P.J. Lester, R. Hurst and N. Bagley. - 1997. Demersal fish community diversity off New Zealand: Is it related to depth, latitude and regional surface phytoplankton? Deep Sea Res, 44: 647-667.

Meuriot, E., P.Y. Dremière and J. Capelle. - 1987. Le chalutage en Méditerranée : le port de Sète. Evolution économique 19701984. Rapp. Econom. Jurid. 3. IFREMER, Sète.

Overholtz, W.J. and A.V. Tyler. - 1985. Long-term responses of the demersal fish assemblages of Georges Bank. Fish. Bull., 83: $507-520$.

Perry, R.I., M. Stocker and J. Fargo. - 1994. Environmental effects on the distribution of groundfish in Hecate Strait, British Columbia. Can. J. Fish. Aquat. Sci., 51: 1401-1409.

Rahel, F.J. - 1990. The hierachical nature of community persistence: a problem of scale. Am. Nat., 136: 328-344.

Rakocinski, C.F., D.M. Baltz and J.W. Fleeger. - 1992. Correspondence between environmental gradients and the community structure of marsh-edge fishes in a Louisiana estuary. Mar. Ecol. Prog. Ser., 80: 135-148.

Ricklefs, R.E. - 1987. Community diversity: relative roles of local and regional processes. Science, 235: 167-171. 
Robert, P. and Y. Escoufier. - 1976. A unifying tool for linear multivariate statistical methods : the RV coefficient. Applied Stat., 25: $257-265$

Roel, B.A. - 1987. Demersal communities off the west coast of south Africa. S. Afr. J. mar. Sci., 5: 575-584.

Taquet, M., J.-C. Gaertner and J. Bertrand. - 1997. Typologie de la flottille chalutière de Sète: formalisation par une méthode de segmentation. Aquat. Living Ressour. 10: 137-148.

Thioulouse, J., D. Chessel, S. Dolédec and J.M. Oliver. - 1996. ADE-4: a multivariate analysis and graphical display software. Stat. Comput., 7: 75-83.

Thrush, S.F., J.E. Hewitt, V.J. Cummings and P.K. Dayton. - 1995. The impact of habitat disturbance by Scallop dredging on marine benthic communities: what can be predicted from the results of experiments? Mar. Ecol. Prog. Ser., 129: 141-150.
Tyler, A.V., W.L. Gabriel and W.J. Overholtz. - 1982. Adaptative management based on structure of fish assemblages of northern continental shelves. Can. Spec. Publ. Fish., 59: 149-156.

Ungaro, N., G. Marano, A. Vlora and M. Martino. - 1998. Spacetime variations of demersal fish assemblages in South-Western Adriatic Sea. Vie Milieu, 48(3): 191-201.

Weinberg, K.L. - 1994. Rockfish assemblages of the middle shelf and upper slope off Oregon and Washington. Fish. Bull., 92: 620-632.

Wiens, J.A. - 1986. Spatial scale and temporal variation in studies of shrubsteppe birds. In: J. Diamond and T.J. Case (eds), Community Ecology, pp. 154-172. Harper \& Row, New York.

Wiens, J.A. - 1989. Spatial scaling in Ecology. Funct. Ecol., 3: 385-397. 